IRA-International Journal of Management \& Social Sciences

ISSN 2455-2267; Vol.05, Issue 03 (2016)

Pg. no. 408-413

Institute of Research Advances

http://research-advances.org/index.php/RAJMSS

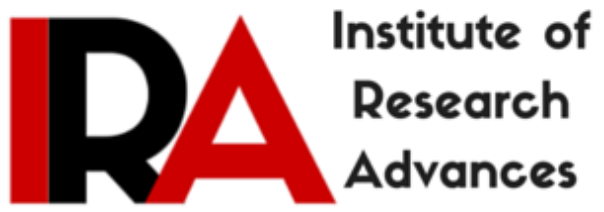

\title{
Self-help Group (SHGs) Activities under DAY- NRLM at Kolar district of Karnataka
}

\author{
Dr. Shankar Chatterjee \\ Professor \& Head (CPME) \\ NIRD \& PR \\ Hyderabad-50030 \\ Telangana, India.
}

Type of Review: Peer Reviewed.

DOI: http://dx.doi.org/10.21013/jmss.v5.n3.p3

\section{How to cite this paper:}

Chatterjee, S. (2016). Self-help Group (SHGs) Activities under DAY-NRLM at Kolar district of Karnataka. IRA-International Journal of Management \& Social Sciences (ISSN 2455-2267), 5(3), 408-413. doi:http://dx.doi.org/10.21013/jmss.v5.n3.p3

(C) Institute of Research Advances

\section{(oc) EY-NC}

This work is licensed under a Creative Commons Attribution-Non Commercial 4.0 International License subject to proper citation to the publication source of the work.

Disclaimer: The scholarly papers as reviewed and published by the Institute of Research Advances (IRA) are the views and opinions of their respective authors and are not the views or opinions of the IRA. The IRA disclaims of any harm or loss caused due to the published content to any party. 


\begin{abstract}
This article is based on field study based carried out in Kolar district of Karnataka by contacting Self-help Group (SHGs) formed under Deendayal Antyaodaya Yojana- National Rural Livelihoods Mission (DAY-NRLM)/Aajeevika which is presently in implementation in the country. This DAYNRLM is the massive self-employment programme which is the off-shoot of restructured scheme of Swarnajayanati Gram Swarojgar Yojana (SGSY). It was launched by the Ministry of Rural Development, Government of India based on Prof Radhakrishna Committee. The study reveals that DAY-NRLM is yet to start with full swing in Kolar district, Karnataka. However, by contacting the two SHGs formed and nurtured under DAY-NRLM it was observed that they were matured enough and earning substantially. It is pertinent to mention that initially the name of the programme was National Rural Livelihoods Mission (NRLM)/Aajeevika but from 26 February 2016, Ministry of Rural Development, Government of India through a notification has rechristened as Deendayal Antyaodaya Yojana so presently it is known as Deendayal Antyaodaya Yojana- National Rural Livelihoods Mission (DAY-NRLM).
\end{abstract}

Key Words: DAY-NRLM, Income, Kolar district and SHG.

\title{
Full Article
}

Kolar district is located in Karnataka, a southern state of India with it's headquarter is also known as Kolar. The district is bounded by the Bangalore Rural district in the west, Chikballapur in the north, Chittoor district of Andhra Pradesh in the east and on the south by Krishnagiri and Vellore districts of Tamil Nadu.

Formerly, Kolar was known in various names such as Kolahala, Kuvalala, Kolala. Kolar Kolahalapura but later finally renamed as Kolar. Historians believe that it was the battlefield for the warring kingdoms of Chalukyas in the north and Cholas to the south, (www.kolar.nic.in). The district is spread over to an area of 374916 hectares home of 1536401 population. The socio-economic particulars may be seen from the table-1.

Table - 1: Kolar district at a glance

\begin{tabular}{|l|l|l|}
\hline $\begin{array}{l}\text { Sl. } \\
\text { No. }\end{array}$ & Item & Issues \\
\hline 1. & Population (2011) & \\
\hline & a) Rural & 1056328 \\
\hline & b) Urban & 480073 \\
\hline & c) Total & 1536401 \\
\hline 2. & Geographical area (in hectare) (As of March 2015) & 374916 \\
\hline & a) Nets area sown & 167666 \\
\hline & b) Area sown more than once & 9009 \\
\hline & c) Main cereals & \begin{tabular}{l} 
Paddy, Maize, Ragi, Tur \& gram \\
\hline 3.
\end{tabular} \\
\hline & Sex ratio (2011) & \\
\hline
\end{tabular}




\begin{tabular}{|c|c|c|}
\hline & b) Urban & 973 \\
\hline & c) Total & 979 \\
\hline \multirow[t]{4}{*}{4.} & $\%$ of SC population to total population (2011) & \\
\hline & a) Rural & 21.30 \\
\hline & b) Urban & 28.84 \\
\hline & c) Total & 30.32 \\
\hline \multirow[t]{4}{*}{5.} & $\%$ of ST population to total population (2011) & \\
\hline & a) Rural & 6.83 \\
\hline & b) Urban & 1.40 \\
\hline & c) Total & 5.13 \\
\hline 6. & $\begin{array}{l}\text { Per capita income of the district's population (in Rs.) (at } \\
\text { constant prices in 2004-05) 2014-15 }\end{array}$ & 35664 \\
\hline 7. & Gram panchayats & 156 \\
\hline \multirow[t]{3}{*}{8.} & Villages & \\
\hline & a) Inhabited & 1599 \\
\hline & b) Uninhabited & 199 \\
\hline \multirow[t]{4}{*}{9.} & BPL card holders (no.) as of March 2015 & \\
\hline & a) Rural & 23564 \\
\hline & b) Urban & 4600 \\
\hline & c) Total & 28164 \\
\hline \multirow[t]{2}{*}{10.} & Normal Rainfall & $724 \mathrm{~mm}$ \\
\hline & In 2014 & $500 \mathrm{~mm}$ \\
\hline
\end{tabular}

Source: www.kolar.nic.in (Dt. 23.11.2016)

Although points in the table are self-explanatory, however few important points as observed from the table are:

Around 67 percent of total population lives in rural areas.

$>$ Area sown is more than once is low

$>$ In recent years district has been getting less rainfall.

$>$ In rural areas sex ratio is higher than urban areas.

$>$ BPL card holders are about six times more in rural areas than urban areas.

Although in this article cases of two SHGs, formed and nurtured, under DAY-NRLM are presented which are based on field study carried out in November 2016, however prior to that few important points about the progress of DAY-NRLM in Kolar district along with salient features of DAY-NRLM are presented here for the benefit of readers. 


\section{Important Features of DAY-NRLM:}

Aajeevika - National Rural Livelihoods Mission (NRLM) was launched by the Ministry of Rural Development (MoRD), Government of India in June 2011. The Mission aims at creating efficient and effective institutional platforms of the rural poor, enabling them to increase household income through sustainable livelihood enhancements and improved access to financial services. NRLM set out with an agenda to cover 7 Crore rural poor households, across districts, blocks, Gram Panchayats and finally at the villages in the country through self-managed Self Help Groups (SHGs) and federated institutions and support them for livelihoods collectives in a period of 8-10 years.

In addition, the poor would be facilitated to achieve increased access to rights, entitlements and public services, diversified risk and better social indicators of empowerment (aajeevika.gov.in/deen-dayalantyodaya-yojana-nrlm). The NRLM has been rechristened as Deendayal Antayodaya YojanaNational Rural Livelihoods Mission (DAY-NRLM) from February 2016. At least one woman member from each identified rural poor household, is to be brought under the Self-help Group (SHG) network in a time bound manner. Special emphasis is particularly on vulnerable communities such as manual scavengers, victims of human trafficking, Particularly Vulnerable Tribal Groups (PVTGs), Persons with Disabilities (PwDs) and bonded labour (aajeevika.gov.in/content/universal-socialmobilization). The beneficiaries, i.e. target groups, are identified through the Participatory Identification of Poor (PIP) method. DAY-NRLM provides Revolving Fund (RF) and Community Investment Fund (CIF) as resources in perpetuity to the institutions of the poor, to strengthen their institutional and financial management capacity and build their track record to attract mainstream bank finance (aajeevika.gov.in/community-funds-resources-perpetuity). It has to be admitted that SHG is a right approach to address the issues of rural women particularly who live below the poverty line (BPL). The author has carried out a large of studies across the country particularly in rural arears of India and observed SHG approach has not only helped to earn income but also empowered them (Chatterjee 2015 and Chatterjee 2013). Many cases SHG leaders were elected in panchayat elections. However the progress of DAY-NRLM is presented in table-1.

Table: 1 DAY-NRLM -Details of SHGs in Kolar district from April 2013 up to Oct. 2016 Details of SHGs in Kolar District \& DAY-NRLM Interest Subsidy Extended (Rs. in lakh)

\begin{tabular}{|c|c|c|c|}
\hline Sl. No. & Particulars & $\begin{array}{l}\text { Total No. } \\
\text { of SHGs. }\end{array}$ & Credit Linked \\
\hline 1 & Total No. of SHGs Credit linked (cumulative) & 10029 & 19033.00 \\
\hline 2 & No. of SHGs where loan outstanding & 7564 & 12190.00 \\
\hline 3 & $\begin{array}{l}\text { No. of SHGs Credit linked during the year (as on } \\
30.06 .2016 \text { ) }\end{array}$ & 1546 & 2442.00 \\
\hline 4 & $\begin{array}{l}\text { No. of SHGs loan renewed during the year (as on } \\
30.06 .2016 \text { ) }\end{array}$ & 396 & 1223.00 \\
\hline 5 & No. of SHGs SB- A/Cs \& Total amount savings & 7313 & 1722.00 \\
\hline 6 & No. of SHGs interest subsidy given under DAY-NRLM & & \\
\hline & a. Total No. of SHGs & 2983 & \\
\hline & b. Int. Subvention (rs.in Lakh) & 66.82 & \\
\hline 7. & $\begin{array}{l}\text { No. of SHGs given RF (Revolving Fund) 2015-16 in the } \\
\text { district }\end{array}$ & 64 & 9.60 \\
\hline 8. & No. Interest taluk in the district (Mulbagal taluk) & \multicolumn{2}{|l|}{ One } \\
\hline 9. & $\begin{array}{l}\text { No. of WLF (Ward Level Federations) formed in } \\
\text { Mulbagal Taluk }\end{array}$ & \multicolumn{2}{|l|}{ Twenty Five } \\
\hline 10. & No. of GPLF (GP Level Federations) in Mulbagal Taluk & \multicolumn{2}{|l|}{ Eight } \\
\hline 11. & Community Investment Fund Received & \multicolumn{2}{|l|}{ Nil } \\
\hline 12. & $\begin{array}{l}\text { No. of SHGs brought under WLF/GPLF of Mulbagal } \\
\text { Taluk }\end{array}$ & \multicolumn{2}{|l|}{230 SHGs } \\
\hline
\end{tabular}

Source: Project Director, Zilla Panchayath, Kolar, Karnataka 
As observed from the above table:

Total number of SHGs credit linked with banks (cumulative) are 10029 with an outlay of Rs.19033.00 Lakh.

$>$ During the time of study the officials informed that there were altogether five taluks, where DAY-NRLM, were in operation and out of five taluks in the district, Mulbagal taluk is the Intensive taluk and wherein eight women SHG federations at GP level were formed involving 230 SHGs.

$>$ Altogether 2983 number of SHGs were provided with interest subvention (subsidy) under DAY-NRLM amounting to Rs. 66.82 Lakh.

$>\quad$ Total amount of savings by 7313 SHGs was Rs. 1722.00 Lakh.

$>$ No SHG was provided with Community Investment Fund.

While discussing with the officials of Kolar district, the following important points were emerged:

* The first women SHG was formed in the country in 1986 at Kamasamudram, Bangarpet taluk of Kolar district.

* Training to SHG members was given for nurturing and development of agriculture / dairy / entrepreneurship development etc. either through NGOs, departments or RSETI. It is pertinent to mention that RSETIs are Rural Self Employment Training Institutes, an initiative of Ministry of Rural Development (MoRD) to have dedicated infrastructure in each district of the country to impart training and skill upgradation of rural youth geared towards entrepreneurship development. RSETIs are managed by banks with active co-operation from the Government of India and State Governments.

* The other major activities were ready-made garments, vermicompost, and food processing.

- In-house training facilities were provided at free of cost to the members of SHGs at Rural Self Employment Training Institute (popularly known as RSETI), which is an initiative of Ministry of Rural Development (MoRD) to have dedicated infrastructure in each district of the country to impart training and skill upgradation of rural youth geared towards entrepreneurship development.

Field Visit:

To get an idea about the functioning of SHGs' income generation activities, a study was carried out in November 2016 by visiting the district and directly members of two self-help groups were contacted. The finding of the study are presented below.

Table: 2 Detail particulars of Sree Nandhini Chowdeshwari Mahila Swsaya Sangha

\begin{tabular}{|l|l|l|}
\hline 01 & Name of the SHG & Sree Nandhini Chowdeshwari Mahila Swsaya Sangha \\
\hline 02. & Address & Markandapura, Vokkaleri GP, Kolar Taluk \\
\hline 03. & Year of Establishment & 1994 \\
\hline 04 & Name of the Activity & Dairy activity and managing milk collection booth at the village \\
\hline 05. & Members of SHG & 20 members BPL \\
\hline 06. & Savings & Rs.5,00,000.00 \\
\hline 07. & Bank Loan & Rs 5 lakh borrowed from Canara Bank and fully repaid \\
\hline 08. & Govt. Grant & Nil \\
\hline
\end{tabular}

Source: Project Director, Zilla Panchayath, Kolar, Karnataka

Table: 3 Detail particulars of Sree Nandhini Annapoorneshwari Mahila Swsaya Sangha

\begin{tabular}{|l|l|l|}
\hline 01 & Name of the SHG & Sree Nandhini Annapoorneshwari Mahila Swsaya Sangha \\
\hline 02. & Address & Markandapura, Vokkaleri GP, Kolar Taluk \\
\hline 03. & Year of Establishment & 1994 \\
\hline 04 & Name of the Activity & Dairy activity and managing milk collection booth at the village \\
\hline 05. & Members of SHG & 15 members BPL \\
\hline
\end{tabular}




\begin{tabular}{|l|l|l|}
\hline 06. & Savings & Rs.5,00,000.00 \\
\hline 07. & Bank Loan & Rs 5 lakh borrowed from Canara Bank and fully repaid \\
\hline 08. & Govt. Grant & Nil \\
\hline
\end{tabular}

Source: Project Director, Zilla Panchayath, Kolar, Karnataka

Since both the SHGs were established at the same time and same village, so there are many common similarities which are presented below:

$>$ Both are situated at Markandapura village of Vokkaleri Gram Panchayat, Kolar Taluk of Kolar district.

$>$ In case both the SHGs, year of establishment was 1994 indicating last 22 years both are functioning which means these are sustainable SHGs.

$>$ Saving of each SHG was Rs. 5 Lakh (each) and also borrowed at the rate of Rs. 5 Lakh each. The positive point is that loan amount was repaid.

$>$ None of the SHG was extended government grant.

$>$ All the members were involved with dairy activity and managing milk collection booth at the village and all had cows and few had buffaloes.

$>$ In case of first SHG, the number of members was more (20) than the second SHG (15).

While discussing with some of the members of both the SHGs namely, Ms. Parvathamama, Ms. Sharadha, Ms. Padma, Ms. Varalaxmi, Ms. Manjula, Ms. Anusuyamma and others, all in unison informed that the activities had facilitated them to scale up their income which was minimum of Rs10,000 per month. As mentioned already, everybody had cows which was in between 1 and 15 in numbers. Milk derived from one cow was minimum of 10 litres per day, as reported.

\section{Conclusion:}

It is evident that because of SHG approach economic conditions of many BPL families in Kolar district have been enhanced as credits were meticulously used for the income generation activities. Thus, it is evident that if any project is meticulously planned and nurtured with pumping of microcredit then livelihood issues of BPL households can be addressed to a great extent. Before conclusion Prof. Muhammad Yunus ( Noble laurate) from his book "Banker to the Poor"; the story of the Grameen Bank", may be quoted, "If the goals of economic development include improved standards of living, removal of poverty, access to dignified employment and reduction in equality then it is quite natural to start women. They constitute the majority of the poor, the under-employed and the economically and socially disadvantaged. Studies undertaken by Grameen, comparing how male borrowers use their loans versus female borrowers, consistently confirm this analysis". He further observes that "Micro-credit may not be a cure-all, but it is a force for change, not only economic and personal, but also social and political".

\section{References:}

1. Chatterjee Shankar (2013) "Employment Programmes \& Rural Development in India", Global Research publications, New Delhi.

2. Chatterjee Shankar (2015) "Rural Development Programmes in India", R.B.S.A. Publishers, Jaipur.

3. http://www.kolar.nic.in

4. http://aajeevika.gov.in/content/welcome-deen-dayal-antyodaya-yojana-nrlm (7th December 2016)

5. http://aajeevika.gov.in/content/universal-social-mobilization (7th December 2016)

6. http://aajeevika.gov.in/content/community-funds-resources-perpetuity (7th December 2016). 